\title{
Pediatric rehydration for moderate dehydration: Comparison of UK and KSA emergency physicians
}

\author{
Muhammad N Qureshi* and Taimur S Butt \\ King Faisal Specialist Hospital and Research Center, Saudi Arabia
}

\begin{abstract}
We performed a meta-analysis of the selected studies comparing Nasogastric Rehydration Therapy (NGT) versus Intravenous Rehydration Therapy (IVT) in children presenting to ED with moderate dehydration due to gastroenteritis. We also conducted a survey of the United Kingdom (UK) and the Kingdom of Saudi Arabia (KSA) Emergency Department (ED) physicians to compare their practice of nasogastric rehydration. The meta-analysis revealed more fluid intake in the first 24hrs, lesser diarrhoea and shorter length of hospital stay in the NGT group. The comparative survey of the physicians showed a decreased use of NGT amongst the KSA physicians. Lesser training in the NGT use seems to be the most common reason for its lesser use.
\end{abstract}

\section{Introduction}

A 3-year-old child is brought to the Emergency Department (ED) with diarrhea and vomiting. An emergency physician estimates him to be suffering from moderate dehydration requiring rehydration. Aware that he may not take oral fluids, and is likely to vomit anyway, you wonder whether nasogastric rehydration or IV fluids is an option for management?

Gastroenteritis is a very common pediatric illness and is the major cause of morbidity and mortality around the world [1,2]. It is a common reason for children presenting to $\mathrm{ED}$ with dehydration. It usually presents with acute onset of diarrhea, which may be accompanied by nausea, vomiting, and abdominal pain [2]. The mechanisms potentially responsible for viral diarrhea include lysis of enterocytes, interference with the brush border function that leads to malabsorption of electrolytes, stimulation of cyclic adenosine monophosphate (cAMP) and carbohydrate malabsorption. The proposed pathophysiology of bacterial gastroenteritis involves the elaboration of toxin by enterotoxigenic pathogens and the invasion with inflammation of mucosa by invasive pathogens $[3,4]$.

Acute diarrhea refers to the passage of loose or watery stools, usually at least three times per 24 hours and lasting less than 14 days [4]. Worldwide, $12 \%$ of deaths among children less than five years of age are due to diarrhea [5]. Diarrhea accounts for 12 to 15 per 1000 admissions of children under the age of 5 years in England [6]. Dehydration accounts for $50 \%$ of the deaths in children and most involve children less than one year of age worldwide $[5,6]$.

The severity of dehydration can be classified as mild (3\% to 5\%), moderate ( $6 \%$ to $9 \%)$ and severe (10\% or greater) [7]. Widespread use of oral rehydration salt solutions began in the 1970 s as an effective and inexpensive method of treating mild to moderate dehydration. The basis for its use lies in the knowledge that glucose enhances sodium and water absorption in the bowel, even during diarrhea $[8,9]$. It can be administered orally and via the nasogastric route. Despite the success of oral rehydration therapy (ORT), its proven efficacy [9] and recommendations for use by various organizations [10], studies show that ORT continues to be underused globally [11], and specifically by physicians in developed countries [8-11].

Predilection towards IVT is very commonly observed amongst Emergency Physicians (EPs). The use of NGT in children for dehydration secondary to gastroenteritis and even for diseases like cholera has been effectively practiced for a long time in developing countries $[12,13]$. Recently conducted studies have shown the use of NGT to be efficacious, cost effective and less time consuming as compared to IVT in developed countries like Australia and USA [1416]. We therefore decided to review the current literature and conduct a brief survey of EPs in the United Kingdom (UK) and Kingdom of Saudi Arabia (KSA) to study their practice patterns in children with moderate dehydration.

\section{Methods}

A clinical scenario was created which included a 3 years old child with moderate dehydration with vomiting and diarrhea due to gastroenteritis. This scenario was presented as a clinical problem to the practicing EPs in the UK \& KSA and we also conducted a search of current literature.

\section{Survey}

A short questionnaire (Appendix A) posing the above clinical scenario was sent electronically to EPs in the UK and the KSA. This survey was designed to inquire into the physician preferences for rehydration of pediatric patients with moderate dehydration. The clinical scenario was of a child with viral gastroenteritis requiring rehydration. The responses were recorded in excel format. The

${ }^{\star}$ Correspondence to: Muhammad N. Qureshi, Consultant Emergency Medicine, DEM Research Director, Assistant Professor Al Faisal University, King Faisal Specialist Hospital and Research Center, Saudi Arabia, E-mail: mnq1711@gmail. com

Received: December 12, 2019; Accepted: January 23, 2020; Published: January 27,2020 
statistical analysis of this survey was done by using the software package SAS version 9.4 (SAS Institute Inc., Cary, NC, USA). Descriptive statistics for the continuous variables are reported as mean \pm standard deviation and categorical variables are summarized as frequencies and percentages. The categorical variables are compared by Chi-square test and the continuous variables are compared by Student's independent $\mathrm{t}$-test. The level of statistical significance is set at $p<0.05$.

\section{Search strategy}

A three-part question was used for literature search; in [children with moderate dehydration] are [nasogastric fluids better than intravenous fluids] at [producing satisfactory rehydration].

PubMed, Google Scholar and Cochrane were searched. Following key words were used; (nasogastric [All Fields] AND versus [All Fields] AND intravenous [All Fields] AND ("fluid therapy"[MeSH Terms] OR ("fluid"[All Fields] AND "therapy"[All Fields]) OR "fluid therapy"[All Fields] OR "rehydration"[All Fields]) AND ("child"[MeSH Terms] OR "child"[All Fields] OR "children"[All Fields]) AND moderate [All Fields] AND ("dehydration"[MeSH Terms] OR "dehydration"[All Fields])) AND ("1966/01/01"[PubDate]: "2018/12/31"[PubDate]).

Randomized controlled trials (RCT) which used NGT as a form of treatment alone or together with ORT comparing with IVT were used for meta-analysis. Children from 2 months to 18 yrs. of age were included in these studies. We compared the RCTs for the amount of fluid intake in the first 24 hours, the Hospital length of stay and duration of diarrhea.

\section{Literature search}

A total of 1956 articles were found with some relevance however, only 20 studies were relevant to our three-part question. Out of these 20 studies, 18 were Randomized Control Trials (RCTs) comparing ORT with IVT. Two were meta-analyses $[22,23]$ also comparing ORT with IVT (one meta-analysis included all 18 RCTs and second included 16) without subgroup comparative analysis of NGT with IVT. We included 5 RCTs for our analysis which used NGT alone or together with ORT as a form of therapy [17-21]. One RCT in Finnish was translated in English before being included in the analysis [17] (Table 1).

\section{Results}

\section{Survey results}

Out of 160 UK EPs who received the questionnaire only 89 (56\%) while 95 (61\%) of 155 KSA EPs completed the survey. 86 (96.63\%) of the UK physicians wanted to start ORT as the first step for pediatric rehydration compared to only 3 (3.15\%) of the KSA EPs. NGT was the choice of 80/86 (93\%) UK practitioners after failure of ORT while none of the KSA practitioners opted for NGT. All of the UK practitioners wanted to start NGT if the IV line was not established compared to only $63(66.31 \%)$ in the KSA group. The main reason for not using NGT was parental concern in the UK EPs while lack of experience was the biggest concern in the KSA group. Other reasons included lack of training, time consumption and fear of nasogastric tube misplacement. The practice of confirming the NG tube placement varied amongst the UK respondents ( $\mathrm{pH}$ monitoring (5\%), X-ray (34\%) and clinical evaluation $(61 \%))$. However, the majority resorted to the use of a premixed commercial oral rehydration solution (Dioralyte ${ }^{\mathrm{TM}}$ ) as the most common solution for the NGT.

\section{Meta-analysis of RCTs comparing NGT with IVT:}

Fluid intake in the $\mathbf{1}^{\text {st }} \mathbf{2 4}$ hours: The following graphic is associated with the meta-analysis on the outcome of fluid intake during the first 24 hours (Graph 1). From among the five studies, three included fluid intake during the first 24 hours as an outcome and could be used in this meta-analysis. In the graphic below, a positive value indicates that the fluid intake during the first 24 hours for the NGT method is more than that for the IVT method. One can see below that overall there is not a significant smaller $(\mathrm{p}<0.05)$ amount of fluid intake during the first 24 hours for the NGT method than for the IVT method.

The length of hospital stay: The following graph is associated with the meta-analysis on the outcome of length of hospital stay (Graph 2). From among the five studies, two included the length of hospital stay as an outcome and could be used in this meta-analysis. In the graphic below, a negative value indicates that the length of hospital stay for the NGT method is less than that for the IVT method. One can see below that overall there is a significant smaller $(\mathrm{p}<0.05)$ length of hospital stay for the NGT method than for the IVT method.

Days of diarrhea: The graph below illustrates the meta-analysis on the outcome, diarrhea (Graph 3). From among the five studies, three included days of diarrhea as an outcome and could be used in this meta-analysis. In the graphic below, a negative value indicates that the number of days of diarrhea for the NGT method is less than that for the IVT method. One can see below that overall there is a significant smaller $(\mathrm{p}<0.05)$ number of days of diarrhea for the NGT method than for the IVT method.
Studyname Qutcome

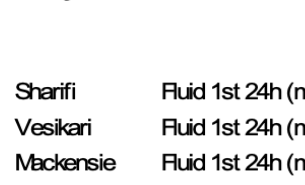

\begin{tabular}{ccrcc} 
& & \multicolumn{4}{c}{ Statistics for each study } \\
\cline { 3 - 5 } $\begin{array}{c}\text { Std diff } \\
\text { in means }\end{array}$ & $\begin{array}{c}\text { Standard } \\
\text { error }\end{array}$ & $\begin{array}{c}\text { Lower } \\
\text { Variance }\end{array}$ & $\begin{array}{c}\text { Ypper } \\
\text { limit }\end{array}$ & $\begin{array}{c}\text { limit } \\
4.479\end{array}$ \\
0.173 & 0.030 & 4.141 & 4.818 \\
0.047 & 0.335 & 0.112 & -0.609 & 0.703 \\
2.073 & 0.243 & 0.059 & 1.596 & 2.549 \\
3.127 & 0.130 & 0.017 & 2.872 & 3.381
\end{tabular}

$\begin{array}{rr}\text { Z-Value } & \text { p-Value } \\ 25.924 & 0.000 \\ 0.140 & 0.889 \\ 8.525 & 0.000 \\ 24.085 & 0.000\end{array}$

Std diff in means and $95 \% \mathrm{Cl}$
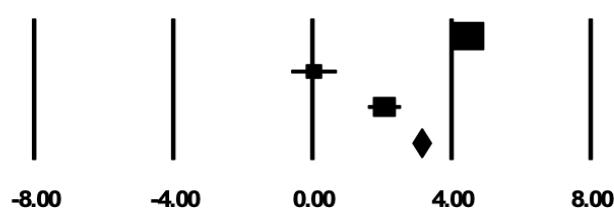

8.00 
Table 1. RCTs included for analysis

\begin{tabular}{|c|c|c|c|c|c|}
\hline $\begin{array}{l}\text { Authors name, } \\
\text { Date, Country }\end{array}$ & Patient Population & Study Type & Outcomes & Key Results* & Comments \\
\hline \multirow{6}{*}{$\begin{array}{l}\text { Sharifi et al. } \\
1985 \\
\text { Iran }\end{array}$} & \multirow{2}{*}{$\begin{array}{l}470 \text { children aged } 1 \text { to } 18 \text { yrs were } \\
\text { randomly allocated to NGT \& IVT } \\
\text { groups. } 151 \text { children were moderately } \\
\text { dehydrated in NGT group }\end{array}$} & \multirow{6}{*}{$\mathrm{RCT}$} & $\begin{array}{l}\text { Failure (worse/ unchanged } \\
\text { within } 2 \text { hrs) }\end{array}$ & One in NGT group & \multirow{3}{*}{$\begin{array}{l}\text { Randomization process not } \\
\text { clear. }\end{array}$} \\
\hline & & & $\begin{array}{l}\text { Weight gain at discharge } \\
\text { (after } 24 \mathrm{hrs} \text { ) }\end{array}$ & $\begin{array}{ll}\text { NGT } & \text { IVT } \\
8.9 \% & 7.2 \% \\
\mathrm{p}<0.001\end{array}$ & \\
\hline & \multirow{3}{*}{$\begin{array}{l}236 \text { given NGT } \\
234 \text { given IVT } \\
\text { All children in NGT group were given } \\
\text { fluid at } 40 \mathrm{mls} / \mathrm{kg} / \mathrm{hr} \text { for } 2 \mathrm{hrs} \text {. IVT } \\
\text { group was given } 20-30 \\
\mathrm{mls} / \mathrm{kg} / \mathrm{hr} \text { or bolus within } 1 \mathrm{hr}\end{array}$} & & Total fluid intake at $24 \mathrm{hrs}$ & $\begin{array}{l}\text { NGT } \quad \text { IVT } \\
846 \mathrm{mls} \quad 680 \mathrm{mls} \\
\mathrm{p}<0.001\end{array}$ & \\
\hline & & & $\begin{array}{l}\text { Complications phlebitis } \\
\text { Abdominal distension } \\
\text { Seizures }\end{array}$ & $\begin{array}{c}\text { NGT } \\
0 \\
4 \\
2\end{array}$ & $\begin{array}{l}\text { Malnourished (36\%) \& } \\
\text { shocked }(21 \%) \text { children } \\
\text { included in NGT group }\end{array}$ \\
\hline & & & Duration of diarrhea (days) & $\begin{array}{cc}\text { NGT } & \text { IVT } \\
4.8 & 5.5 \\
\mathrm{p}<.001 & \end{array}$ & $\begin{array}{l}\text { Death occurred in } \\
\text { malnourished children. }\end{array}$ \\
\hline & $\begin{array}{l}\text { All children were breast fed or given } \\
\text { formula milk within } 24 \text { hrs. }\end{array}$ & & Death (3-8 days post therapy) & $\begin{array}{cc}\text { NGT } & \text { IVT } \\
2 & 5\end{array}$ & *mean (SD) \\
\hline \multirow[t]{5}{*}{ Vesikari et al.. } & \multirow{2}{*}{$\begin{array}{l}37 \text { children }<5 \text { yrs moderately } \\
\text { dehydrated children randomly } \\
\text { allocated to treatment groups }\end{array}$} & \multirow{5}{*}{$\mathrm{RCT}$} & Weight gain by 12 hrs (grams) & $\begin{array}{ll}\text { ORT } & \text { IVT } \\
285 & 103\end{array}$ & \multirow{5}{*}{$\begin{array}{l}\text { Small number of children. } \\
\text { Blinding process not clear. } \\
\text { Fluid deficit was } \\
\text { inconsistently corrected } \\
\text { Only } 13 \text { children were given } \\
\text { NGT (selection criteria not } \\
\text { mentioned) } \\
\text { *mean (SD) }\end{array}$} \\
\hline & & & $\begin{array}{l}\text { Total fluid intake (mls) } \\
0-6 \mathrm{hrs} \\
6-12 \mathrm{hrs}\end{array}$ & $\begin{array}{ll}\text { ORT } & \text { IVT } \\
823(399) & 671(272) \\
316(98) & 486(201) \\
\end{array}$ & \\
\hline & $\begin{array}{l}22 \text { given ORT } \\
15 \text { given IVT }\end{array}$ & & Duration of diarrhea (days) & $\begin{array}{ll}\text { ORT } & \text { IVT } \\
4.1(1.5) & 4.8(2.3)\end{array}$ & \\
\hline & \multirow{2}{*}{$\begin{array}{l}\text { Both groups had } 2 / 3 \text { rd fluid } \\
\text { deficit replaced within } 6 \mathrm{hrs} \\
\text { followed by maintenance }\end{array}$} & & $\begin{array}{l}\text { Number of patients with } \\
\text { uncomplicated restart of feeds at } \\
12 \mathrm{hrs}\end{array}$ & $\begin{array}{ll}\text { ORT } & \text { IVT } \\
17 & 6\end{array}$ & \\
\hline & & & $\begin{array}{l}\text { Failures (children in ORT } \\
\text { group needing IV fluids) }\end{array}$ & $\begin{array}{l}2 \text { children in ORT group without } \\
\text { NGT (one had consumed } \\
\text { insufficient fluids by } 6 \text { hrs and } \\
\text { other had continuous vomiting) }\end{array}$ & \\
\hline $\begin{array}{l}\text { Mackenzie et al. } \\
1991\end{array}$ & \multirow{2}{*}{$\begin{array}{l}111 \text { children aged } 3 \text { to } 36 \\
\text { months with diarrhea }<7 \\
\text { days \& moderate dehydration } \\
\text { randomized to treatment groups }\end{array}$} & \multirow{5}{*}{$\mathrm{RCT}$} & $\begin{array}{l}\text { Failures (children in oral group } \\
\text { needing IV fluids) }\end{array}$ & $\begin{array}{l}\text { Two failures in ORT group Both } \\
\text { had intractable vomiting (NG } \\
\text { fluids were not tried in these } \\
\text { children) }\end{array}$ & \multirow{5}{*}{$\begin{array}{l}\text { ORT \& NGT group analyzed } \\
\text { together. } \\
\text { Inconsistency in replacing } \\
\text { fluids in both groups. } \\
\text { IVT group also given oral } \\
\text { fluids during first } 24 \text { hrs } \\
7 \text { children in IVT group } \\
\text { developed redness at the drip } \\
\text { site. }\end{array}$} \\
\hline \multirow[t]{4}{*}{ Australia } & & & $\begin{array}{l}\text { Fluid intake }(\mathrm{mls} / \mathrm{kg}) \\
0-6 \mathrm{hrs} \\
0-24 \mathrm{hrs}\end{array}$ & $\begin{array}{ll}\text { ORT } & \text { IVT } \\
63(41-81) & 47(39-57) \\
94(79-142) & 122(90-147) \\
\mathrm{P}<0.05 & \end{array}$ & \\
\hline & \multirow{3}{*}{$\begin{array}{l}52 \text { given ORT } \\
52 \text { given IVT } \\
\text { Oral therapy was replaced over } 6 \mathrm{hrs} \\
\text { and IV over } 24 \mathrm{hrs}\end{array}$} & & $\begin{array}{l}\text { No. of vomits }(0-24) \\
\text { No. of stools }(0-24)\end{array}$ & $\begin{array}{ll}1(0-2) \text { ORT } & 0(0-0) \text { IVT } \\
5(1-10) \text { ORT } & 4(1-6) \text { IVT }\end{array}$ & \\
\hline & & & Weight at $24 \mathrm{hrs}(\mathrm{kg})$ & $\begin{array}{l}11.2(9.5-12.5) \text { ORT } \\
11.3(9.8-12.3) \text { IVT }\end{array}$ & \\
\hline & & & Length of hospital stay (days) & $\begin{array}{ll}2.0(2.0-4.0) & \text { ORT } \\
2.0(2.0-3.0) & \text { IVT }\end{array}$ & \\
\hline Gremese et al. & \multirow{4}{*}{$\begin{array}{l}24 \text { children aged } 2 \text { to } 24 \text { months of } \\
\text { age with unsuccessful oral rehydration } \\
\text { (secondary to vomiting and refusal of } \\
\text { fluids) were randomized to NGT and } \\
\text { IVT groups }\end{array}$} & \multirow{6}{*}{$\mathrm{RCT}$} & $\begin{array}{l}\text { Failures (children requiring IVT due } \\
\text { to persistent vomiting) }\end{array}$ & $\begin{array}{l}\text { One in NGT group (secondary to } \\
\text { persistent vomiting) }\end{array}$ & \multirow{6}{*}{$\begin{array}{l}\text { Oral rehydration was tried } \\
\text { on all these children before } \\
\text { enrolment in study }\end{array}$} \\
\hline \multirow[t]{5}{*}{ USA } & & & Duration of rehydration (hrs) & $\begin{array}{lc}\text { NGT } & \text { IVT } \\
5.8(0.5) & 7.1(1.2)\end{array}$ & \\
\hline & & & $\begin{array}{l}\text { Duration of diarrhea }(\mathrm{h}) \text { Duration of } \\
\text { vomiting }(\mathrm{h}) \\
\text { (After admission) }\end{array}$ & $\begin{array}{lc}\text { NGT } & \text { IVT } \\
23.3(7.0) & 43.9(8.2) \\
5.8(0.5) & 7.1(1.2)\end{array}$ & \\
\hline & & & Daily cost of hospitalization ( $\$$ /day) & $\begin{array}{lc}\text { NGT } & \text { IVT } \\
870(114) & 1,064(133)\end{array}$ & \\
\hline & All children were $5-10 \%$ dehydrated & & Duration in hospital (days) & $\begin{array}{lc}\text { NGT } & \text { IVT } \\
2.8(0.4) & 1.8(0.3)\end{array}$ & \\
\hline & Fluid deficit replaced over $6 \mathrm{hrs}$ & & Complications & $\begin{array}{l}\text { No complications seen in either } \\
\text { group }\end{array}$ & \\
\hline
\end{tabular}




\begin{tabular}{|c|c|c|c|c|c|c|}
\hline \multirow{5}{*}{$\begin{array}{l}\text { Nager et al. } \\
2002 \\
\text { USA }\end{array}$} & \multirow{5}{*}{$\begin{array}{l}96 \text { children aged } 3 \text { to } 36 \text { months with } \\
\text { diarrhea }<7 \text { days and vomiting were } \\
\text { randomly allocated to rapid NGT and } \\
\text { rapid IVT } \\
46 \text { given NGT } \\
44 \text { given IVT } \\
\text { Both the groups were given fluids at a } \\
\text { rate of } 50 \mathrm{mls} / \mathrm{kg} \text { over } 3 \mathrm{hrs} \text { followed } \\
\text { by oral fluids }\end{array}$} & \multirow{5}{*}{$\mathrm{RCT}$} & $\begin{array}{l}\text { Failures } \\
\text { (Children who vomited } 3 \text { times after } \\
\text { start of NGT }\end{array}$ & \multicolumn{2}{|l|}{ None } & \multirow{5}{*}{$\begin{array}{l}\begin{array}{l}\text { Oral fluid challenge } \\
\text { was given to all children prior } \\
\text { to enrolment. } \\
\text { Assessors blinded } \\
3 \text { children with persistent } \\
\text { emesis excluded ( } 2 \text { IVT \& } 1 \\
\text { NGT group) } \\
\text { Telephone follow up after } \\
24 \text { hrs } \\
8 \text { NGT \& } 7 \text { IVT group } \\
\text { children returned after } 24 \mathrm{hrs} \\
\text { (none needed admission) }\end{array}\end{array}$} \\
\hline & & & $\begin{array}{l}\text { Safety and efficacy } \\
\text { Mean per case failure rate }\end{array}$ & \multicolumn{2}{|c|}{\begin{tabular}{|ll} 
NGT & IVT \\
$4.3 \%$ & $61.4 \%$ \\
$\mathrm{P}<0.0001$ & \\
\end{tabular}} & \\
\hline & & & $\begin{array}{l}\text { Weight gain } \\
\text { Grams } \\
\text { Percentage body weight }\end{array}$ & $\begin{array}{l}\text { NGT } \\
220 \\
2.21\end{array}$ & $\begin{array}{l}\text { IVT } \\
350 \\
3.58\end{array}$ & \\
\hline & & & Cost per patient (\$) & \begin{tabular}{|l} 
NGT \\
525.90
\end{tabular} & $\begin{array}{c}\text { IVT } \\
642.64\end{array}$ & \\
\hline & & & Complications & \multicolumn{2}{|c|}{ No significant difference } & \\
\hline
\end{tabular}

Study name outcome

\begin{tabular}{llrrrrrrrr} 
& & $\begin{array}{c}\text { Std diff } \\
\text { in means }\end{array}$ & $\begin{array}{c}\text { Standard } \\
\text { error }\end{array}$ & \multicolumn{2}{c}{$\begin{array}{c}\text { Variance } \\
\text { Mackensie }\end{array}$} & $\begin{array}{c}\text { Lower } \\
\text { limit }\end{array}$ & $\begin{array}{c}\text { Upper } \\
\text { limit }\end{array}$ & Z-Value & p-Value \\
Gremese & Length of stay (days) & 0.000 & 0.196 & 0.038 & -0.384 & 0.384 & 0.000 & 1.000 \\
& Length of stay (days) & -2.828 & 0.57 & 0.333 & -3.960 & -1.697 & -4.899 & 0.000 \\
& & -0.293 & 0.186 & 0.034 & -0.657 & 0.071 & -1.576 & 0.115
\end{tabular}

\section{Statistics for each study}

0.115

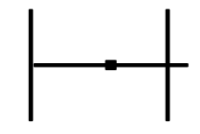

$-4.00$
Std diff in means and $95 \% \mathrm{Cl}$

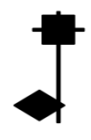

0.00

200

4.00

Favours A

Favours B

\section{Meta Analysis}

Graph 2. The following graph is associated with the meta-analysis on the outcome of length of hospital stay

Study name Outcome

\begin{tabular}{|c|c|c|c|c|c|c|c|c|}
\hline & & $\begin{array}{c}\text { Std diff } \\
\text { in means }\end{array}$ & $\begin{array}{l}\text { Standard } \\
\text { error }\end{array}$ & Variance & $\begin{array}{l}\text { Lower } \\
\text { limit }\end{array}$ & $\begin{array}{l}\text { Upper } \\
\text { limit }\end{array}$ & Z-Value & $\mathrm{p}-\mathrm{Val}$ \\
\hline Sharifi & Darrhea (days) & -0.277 & 0.093 & 0.009 & -0.458 & -0.095 & -2.985 & \\
\hline Vesikari & Darrihea (days) & -0.376 & 0.338 & 0.114 & -1.038 & 0.286 & -1.113 & \\
\hline Gremese & Darrhea (days) & -2.722 & 0.567 & 0.321 & -3.832 & -1.611 & -4.804 & \\
\hline & & -0.343 & 0.088 & 0.008 & -0.516 & -0.170 & -3.883 & \\
\hline
\end{tabular}

Std diff in means and $95 \% \mathrm{Cl}$

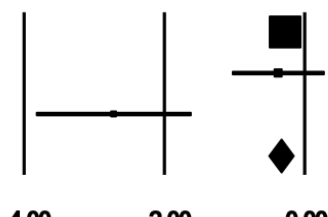

0.00

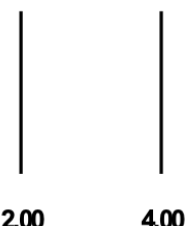

Favours B

\section{Meta Analysis}

\section{Discussion}

Our meta-analysis, indicates that nasogastric rehydration is an effective alternative to IVT in moderately dehydrated children. There was no significant difference in the amount of fluid intake in the first 24hrs, more weight gain and lesser length of hospital stay in the NGT group. However, our case based survey shows that the EPs in the KSA prefer IVT as their first line treatment for rehydrating a child with moderate dehydration in the ED, while the UK EPs preferred to try ORT/NGT before starting the IVT.
Graph 3. The graph above illustrates the number of days of diarrhea between the NGT and the IVT group

Nasogastric rehydration is safe to use in children of all ages $[16,23,24]$. Rehydration through an NGT can be particularly useful in children with moderate dehydration, where rapid correction of hydration might prevent hospitalization [16,18,19,21]. Rapid NGT rehydration is well tolerated, leads to much quicker replenishment of fluid deficit and maintenance of weight gain in the first $6 \mathrm{hrs}$ [16$18,21]$. NGT rehydration helps the child restart his feeds quicker, which greatly improves the outcome of dehydration [23,25]. It is associated with fewer complications as there is less rapid shift of electrolytes and 
more rapid correction of acidosis [24,26]. Continuous slow nasogastric rehydration can be used in the presence of vomiting, as correction of acidosis and dehydration lessens the frequency of vomiting $[25,26]$. The use of single oral dose ondansetron in children with gastroenteritis has also reduced the incidence of vomiting and frequency of IV fluid rehydration [27,28]. Gremese and Nager et al. found NGT as a costeffective therapy in the ED compared to IVT ( $\$ 525.90$ vs. $\$ 642.64$ / patient). The two previous systematic reviews [21,22] did not find any difference in the amount of weight gained between treatment groups but they only compared ORT with IVT groups without analyzing the NGT group separately. Our meta-analysis showed weight gain in the NGT group was significant.

NGT risks may include aspiration due to misplacement, pain, epistaxis but the benefits probably outweigh these risks [27-29]. Nasogastric tube can be easily inserted and its gastric placement can be confirmed with a pH test of aspirated fluid $(<5.5)$ [27,30-32]. NGT should not be used in cases of paralytic ileus, in severe hypovolemia or shock. In such cases IVT is the modality of choice [23-28]. IVT has its own risks including; requiring multiple attempts to place the cannula, extravasation of infused fluids into the soft tissues, phlebitis, or cellulitis at the puncture site and a failure rate requiring intraosseous route [23-25].

Despite the European Society of Gastroenterology, Hepatology \& Nutrition (ESPGHAN) guidelines for rehydration in gastroenteritis with emphasis on ORT and NGT prior to IVT, the clinical practice guidelines (CPGs) in various European countries vary significantly [33-37]. The use of NGT is less common in EPs without pediatric emergency specialty experience [32]. A lot of variation in the use of NGT also exists among various pediatric emergency departments across Europe [36]. Majority of the European pediatric practitioners start ORT as the first line therapy with significant difference in the second line therapy [36,37]. Parental preference of IVT as a second line therapy does influence EPs behavior in the choice of therapy [34].

In our survey, the lack of provider experience with NGT was the main deterrent. The fear of wrong placement, discomfort to the child, parental concerns and increased time consumption with NGT were other reasons preventing its use. ED resources should include appropriately trained nursing staff and supplies to facilitate NGT. Evidence based practice, protocol driven management, and scenario based simulation training of EPs will increase awareness and confidence in its use.

\section{Limitations}

None of the trials was double blinded due to the nature of the intervention. There was no allocation concealment. The methods confirming the placement of NG tube have not been mentioned.

\section{Conclusions}

NGT has equivalent efficacy compared to IVT in children with moderate dehydration secondary to gastroenteritis. It is a safe and effective way of rehydration for children in the ED as it may decrease patient's length of stay. NGT is still under-utilized in the KSA; training and awareness of the EPs may increase its utilization as a treatment option.

\section{References}

1. Gastroenteritis, Subcommittee on Acute (1996) Practice parameter: the management of acute gastroenteritis in young children. Pediatrics 97: 424-435.
2. World Health Organization (1996) The challenge of diarrhoeal and acute respiratory disease control. Point of Fact No 77. Geneva: World Health Organization 1-4.

3. Amieva Manuel R (2005) Important bacterial gastrointestinal pathogens in children: a pathogenesis perspective. Pediatric Clinics 52: 749-777.

4. Colletti, James E, Brown KM, Ghazala Q, Isabel A, et al. (2010) The management of children with gastroenteritis and dehydration in the emergency department. The Journal of Emergency Medicine 38: 686-698.

5. World Health Organization (2009) Diarrhoea: why children are still dying and what can be done.

6. Phillips RS (2002) Evidence Based Pediatrics and Child Health: Edited by VA Moyer, EJ Elliott, RL Davies, et al. London: BMJ Books: 139-139.

7. Gareth J, Steketee RW, Black RE, Bhutta ZA, Morris SS, et al. (2003) How many child deaths can we prevent this year? The lancet 362: 65-71.

8. Gavin, Norma, Merrick N, Davidson B (1996) Efficacy of glucose-based oral rehydration therapy. Pediatrics $98: 45-51$.

9. Gregory PC, Barker WH, Mushlin AI, Julius GK Goepp (2000) Oral versus intravenous: rehydration preferences of pediatric emergency medicine fellowship directors. Pediatric Emergency Care 16: 335-338.

10. Philip OO, Avner JR, Stein REK (2002) Oral rehydration, emergency physicians, and practice parameters: a national survey. Pediatrics 109: 259-261.

11. Reis, Cohen E, Goepp JU, Katz S, Santosham M (1994) Barriers to use of oral rehydration therapy. Pediatrics 93 : 708-711.

12. Snyder JD (1991) Use and misuse of oral therapy for diarrhea: comparison of US practices with American Academy of Pediatrics recommendations. Pediatrics 87: 28-33.

13. Santosham M (2002) Oral rehydration therapy: reverse transfer of technology. Archives of Pediatrics \& Adolescent Medicine 156: 1177-1179.

14. Garland JS, Peter HW, Dunne M, Hintermeyer M, Bozzette MA, et al. (1992) Peripheral intravenous catheter complications in critically ill children: a prospective study. Pediatrics 89: 1145-1150.

15. Stephen BF, Keating LE, Rumatir M, Schuh S (2012) Health care provider and caregiver preferences regarding nasogastric and intravenous rehydration. Pediatrics 130: e1504-e1511.

16. Arch Pediatr. 2017 Jun;24(6):527-533. doi: 10.1016/j.arcped.2017.03.006. Epub 2017 Apr 14. (proves NGT better, with slightly more adverse effects in NGT)

17. Sharifi J, Ghavami F, Nowrouzi Z, Fouladvand B, Malek M, et al. (1985) Oral versus intravenous rehydration therapy in severe gastroenteritis. Archives of Disease in Childhood 60: 856-860.

18. Vesikari, Timo, Isolauri E, Baer M (1987) A comparative trial of rapid oral and intravenous rehydration in acute diarrhoea. Acta Pcediatrica 76: 300-305.

19. Mackenzie, Angela, Barnes (1991) Randomised controlled trial comparing oral and intravenous rehydration therapy in children with diarrhoea. BMJ 303: 393-396.

20. David AG (1995) Effectiveness of nasogastric rehydration in hospitalized children with acute diarrhea. Journal of Pediatric Gastroenterology and Nutrition 21: 145-148.

21. Nager AL, Wang VJ (2002) Comparison of nasogastric and intravenous methods of rehydration in pediatric patients with acute dehydration. Pediatrics 109: 566-572.

22. Fonseca BK, Anna H, Craig JC (2004) Enteral vs intravenous rehydration therapy for children with gastroenteritis: A meta-analysis of randomized controlled trials. Archives of Pediatrics \& Adolescent Medicine 158: 483-490.

23. Lisa H, Bellemare S, Wiebe N, Russell KF, Klassen TP, Craig WR (2006) Oral versus intravenous rehydration for treating dehydration due to gastroenteritis in children. Cochrane Database of Systematic Reviews 3.

24. Gonzalez-Adriano SR, Valdes-Garza HE, Garcia-Valdes LC (1988) Oral hydration versus intravenous hydration in patients with acute diarrhea. Boletin Medico Del Hospital Infantil de Mexico 45: 165.

25. Philip RS, Alessandrini EA, Joffe MD, Localio R, Shaw KN (2005) Oral versus intravenous rehydration of moderately dehydrated children: a randomized, controlled trial. Pediatrics 115: 295-301.

26. Clarke, Sonya, Richardson O (2007) A review of nasogastric tube management in children 2: Position, placement error and hydration. Journal of Children's and Young People's Nursing 1: 119-128. 
27. National Patient Safety Agency (2007) Promoting safer measurement and administration of liquid medicines via oral and other enteral routes. Patient Safety Alert 19: 1-12.

28. Fedorowicz Z, Alhashimi D, Alhashimi H (2007) Meta $\square$ analysis: ondansetron for vomiting in acute gastroenteritis in children. Alimentary Pharmacology \& Therapeutics 26: $1086-1086$.

29. J Paediatr Child Health. 2008 Oct;44(10):560-3. doi: 10.1111/j.14401754.2008.01335.x. Epub 2008 Jun 18.

30. Harvard study proving oral rehydration better and zofran oral/iv reduces risk of vomiting. J Emerg Med 38(5): 686-98.
31. Pediatrics. 2011 Mar;127(3):e748-57. doi: 10.1542/peds.2010-0952. Epub 2011 Feb 14.

32. Cheng A (2011) Emergency department use of oral ondansetron for acute gastroenteritisrelated vomiting in infants and children. Paediatrics \& Child Health 16: 177-179.

33. Pediatrician $v s$ non-paediatrician. Pediatr Emerg Care 28(4): 322-8.

34. Scientific World Journal. 4; 828157.

35. Failed comparitive trial Klin Padiatr. 226: 19-23.

36. BMC Pediatr. 16: 125 .

37. J Pediatr Gastroenterol Nutr. 63(2): 226-35.

Copyright: $\odot 2020$ Qureshi MN. This is an open-access article distributed under the terms of the Creative Commons Attribution License, which permits unrestricted use, distribution, and reproduction in any medium, provided the original author and source are credited. 